\title{
Rehearsal Model as the Practicum Model in Preparing Professional Pre-service English Teachers
}

\author{
Evi Fatimatur Rusydiyah \\ Head of Faculty of Tarbiyah and Teacher Training Laboratory Department \\ Universitas Islam Negeri Sunan Ampel Surabaya \\ Surabaya, Indonesia \\ evi_fatimatur@yahoo.com
}

\begin{abstract}
Practicum module in the Faculty of Tarbiyah and Teacher Training at UIN Sunan Ampel Surabaya has not been integrated fully with other modules offered. However, the Faculty offers Microteaching module (PPL1) and Internship module (PPL2) as two practicum modules available. Microteaching module (PPL1) had not trained students for real classroom condition. Therefore, an innovation to improve previous practicum system has been applied through the implementation of Rehearsal Model. The purpose of this study is to find out the implication of Rehearsal Model implementation in preparing professional pre-service teachers. The result shows that students were more ready, more motivated, and that they gained more self-confidence, and they studied harder. It is assumed that Rehearsal Model is a suitable model to be applied in Practicum module.
\end{abstract}

Keywords-Rehearsal Model, Practicum, Microteaching, Internship

\section{BACKGROUND OF THE STUDY}

One of the main principals of higher education institution is to have a system that produces high qualified graduates. This system lead to four important components: input, process, output and outcome. These four components could function properly if supported with curriculum design that is adaptive to the changes of environment and technology. Higher education curriculum is a set of plans and arrangements regarding the content, the study materials, the delivery method and the assessment system used as guidelines for the implementation of teaching and learning activities in universities (The copy of Government Regulation on Research, Education and Technology No. 44/ 2015 article 1). Higher education institution needs to measure their graduates: Do the graduates own the targeted skills that are compatible with the learning achievement stated in KKNI qualification?

The Faculty of Tarbiyah and Teacher Training at UIN Sunan Ampel Surabaya as one of the Pre-service Teacher Institutions in Indonesia is responsible to produce qualified English teachers. Therefore, the curriculum used should be suitable and has a good quality. One of the important part of the curriculum is the practicum modules (PPL). The practicum modules had not been integrated with other modules, but to stand alone as Micoteaching module (PPL1) and Internship module (PPL2). In addition to these two modules, there are several other modules which have applied practicum model. However, the teaching practicum activity is accumulated in Micoteaching module (PPL1). The two practicum modules serve as important program in preparing professional pre-service teachers. Mictroteaching is a learning and teaching method which is based on performance. The technique used is the adaptation of teaching and learning components in order for pre-service teachers to master each component in a simplified context (Marno and Idris, 2008: 71). Similar to Marno and Idris' idea, Allen and Ryan (in Hodkinson and Phil, 1994) stated that micro teaching is a practicum concept which can be applied in various stages in the development of teaching personnel, both for those in in-service training and those in pre-service training.

Several advantages of practicum modules (PPL) for preservice teachers are (Field Experience Guidance Book, 2015:3):

1. Pre-service teachers can apply and develop their knowledge throughout Microteaching and Internship program based on their students' needs.

2. Students will get the chance to see and feel the physical and psychological environment of an education institution so that it would give them real experience.

3. Pre-service teachers will improve their skill and professionalism.

4. Pre-service teachers will gain more understanding of the importance of education because they have experience real context.

Microteaching module (PPL1) offers in the Faculty of Tarbiyah and Teacher Training of UIN Sunan Ampel Surabaya had not given experience for pre-service teachers to interact with teachers and students at schools. Microteaching module (PPL1) was conducted in microteaching laboratory applying peerteaching techniques throughout the 16 meetings. It made Microteaching activity monotone and did not prepare students to face the real context. 
Some of the causes are as follow:

a. Microteaching module (PPL1) was conducted as practice, observe, and reflection classes.

b. Peerteaching was conducted throughout the 16 meetings.

c. Micrtoteaching module (PPL1) guide book did not describe real teaching context.

d. Lecturers' journal only served as routine that needed to be filled with summary and feedback.

e. The lack of a model that combines microteaching and realteaching.

Considering the complexities of preparing professional and qualified English teachers, the Faculty of Tarbiyah and Teacher Training of UIN Sunan Ampel Surabaya have made the revision of Microteaching module (PPL1) so that students will experience real classroom context.

The focus of this study is to analyze whether Rehearsal Model implemented in Microteaching module (PPL1) was suitable in preparing pre-service teachers to take Internship module (PPL2) and so become professional English teachers. The purpose of this study is to find out how the Rehearsal Model was implemented to reach its goal.

\section{RESEARCH Methodology}

This study was conducted through a survey to the preservice teachers of English Education and Teacher Training Department who have taken the first part of Microteaching module (PPL1). When the survey was conducted, the preservice teachers were doing the second part of Internship program for two months. Students should take Internship program as a pre-requisite in taking bachelor thesis module.

The survey was filled by 121 English Education and Teacher Training Department pre-service teachers. Some did not fill in the survey because they were not informed and that they were lazy to fill in the survey. Some others said that they did not fill in the survey because of the unavailability of internet connection.

This survey did not consider gender and origins such as whether the pre-service teachers live in urban or rural area. This survey was filled in online through a google form which was designed by the Faculty of Tarbiyah and Teacher Training Laboratory of UIN Sunan Ampel Surabaya. The result of the survey was supported by interview with the lecturers and class observation.

The questions in the survey were designed according to the 6 steps developed by Lampert, et.al (2013): observation, collective analysis, preparation, rehearsal, classroom enactment, and collective analysis. The items questioned related to Rehearsal Model were about: (1) whether preservice teachers were given chances in developing their general knowledge in the teaching and learning program, (2) whether pre-service teachers designed lesson plans according to the context of the school and its students, (3) whether preservice teachers learned how to manage class effectively, (4) whether pre-service teachers designed good quality learning media, (5) whether pre-service teachers learned about basic teaching skills, (6) whether pre-service teachers learned how to solve problems according to their students' characteristics, (7) whether pre-service teachers practicing innovative and creative teaching activities, (8) whether pre-service teachers needed more than 2 credits module to learn, and (9) whether literacy based activities were implemented. Each item was given 4 choices of answers: strongly agree, agree, neutral, disagree.

\section{THEORETICAL FRAMEWORK}

Teacher professional development has been discussed by educational observers. One topic discussed is the preparation for professional pre-service teacher. One of the programs intended is the practicum program which is developed through university curriculum. The model suitable is the microteaching model. Conventional Microteaching program only focuses on microteaching activity and does not involve real teaching. The advantage of Microteaching Model is the numerous chances given to the pre-service teachers to practice their teaching skill. On the other hand, the disadvantage of this model is the use of unreal classroom context. Pre-service teachers only face imitative condition with the absence of real students' characteristics. Because, the students are their own classmates. This condition is certainly different compare to real context. In conclusion, conventional microteaching program does not integrate inclass teaching with real context teaching.

On the contrary, modern microteaching combines the two elements. The system used in modern microteaching is the interconnecting system. According to Lampert, et.al (2013), students will have higher readiness level when they have the chance to teach in real context. The advantage of this model is to expose students with real condition and problems in schools.

Microteaching model that is based on the integration of microteaching and real teaching is developed by Lampert, et.al (2013). They had developed the Rehearsal Model or the enactment and investigation cycle. Rehearsal Model consists of 6 steps: observation, collective analysis, preparation, rehearsal, classroom enactment, and collective analysis.

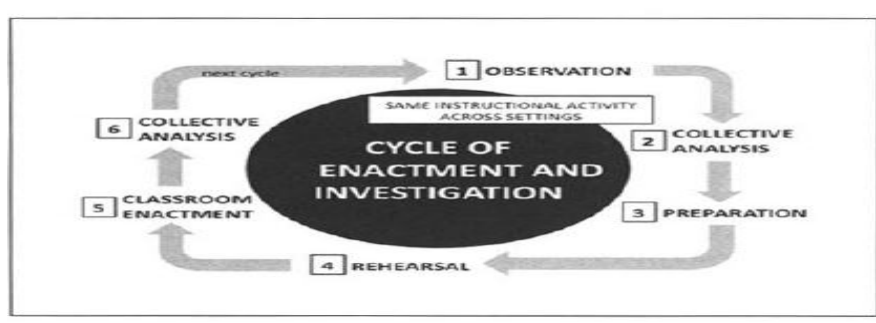

Fig. 1. Enactment and investigation cycle by Lampert, et.al (2013)

Rehearsal Model implementation as above is applied so that Microteaching module (PPL1) can integrate in-class teaching and real teaching. This combination is hoped to help pre-service teachers to be professional English teachers. This integration is believed to lead to the contextual training pattern in which pre-service teachers do not only teach their 
classmates, but also experience real teaching. The integration steps are: introduction, real class observation, analyzing data from observation, preparation, microteaching and reflection, realteaching, reflection, reflection for whole course and exhibition plan. The steps can be seen from the following picture.

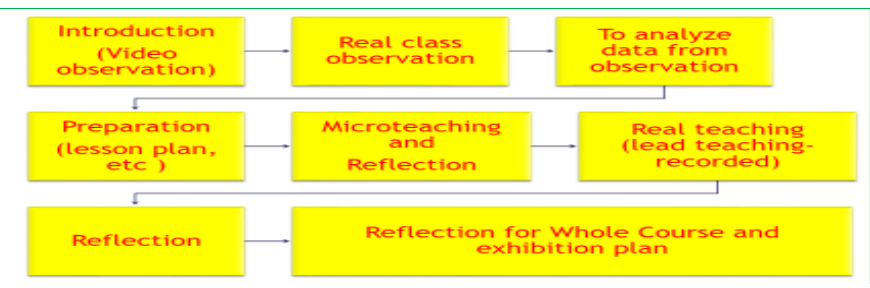

Fig. 2. The Sequences of Microteaching Course

The flow of the activities can be elaborated as follow: (1) Introduction to subject and video observation. Intro to subject covers: (a) lecturer introduction, (b) classroom rules, (c) syllabus, (d) activities, (e) assignments, (d) assessment, (e) video observation, (f) video discussion; (2) Real Class Observation. This activity will be conducted by asking preservice teachers to observe teaching and learning activity in our partner schools. Pre-service teachers will come to the classroom to do class modelling and conducted a child case study; (3) Data Observation Analysis. The data is gathered through observation which should have been done in the second step; (4) Preparation (lesson plan, etc.). This activity is the preparation step towards peerteaching activity. The observation video and modelling will be the basis in preparing the learning media (syllabus, lesson plan, media, handout, and assessment rubric); (5) Microteaching and Reflection. This activity is to have a teaching rehearsal; (6) Realteaching (leadteaching-recorded). The idea is to have the input from peerteaching implemented in real classroom context. To help the lecturers conduct a reflection, students' realteaching will be recorded and will be shown in the Microteaching class; (7) Reflection. What will be reflected upon are the videos of pre-service teachers' peerteaching and realteaching; (8) Reflection for whole course and exhibition plan.

\section{THE RESUlt OF THE STUdY}

The result shows significant improvement. Through observation, collective analysis, rehearsal, realteaching, and reflection steps as the four main parts of the whole steps, data shows that Microteaching module (PPL1) using Rehearsal Model receives excellent feedback from preservice teachers. They chose 'agree' and 'strongly agree' on many items in the survey. Data also shows that Rehearsal Model is a dominant factor in pre-teachers' teaching skill improvement and their level of professionalism. Rehearsal Model also follows the newest trend on teacher professional development, especially activities involving teacher observation, peer observation, pre-service teacher - lecturer collaboration, and pre-service teacher - university/ school collaboration. The strength of Rehearsal Model shows that giving professional autonomy to pre-service teacher will provide strength for them to decide their own learning path (C.Galambos, 1986).

The data gathered is also supported by the idea of Lampert et.al (2013) which then developed by Kazemi, et.al (2015) who found that given a chance to rehears, pre-service teachers will create their own pattern through the process. The impact will be greater if the rehearsal step is not only presented in the Microteaching class but in the real context. This study support the study conducted by Lampert et.al (2013) which inspire the idea of interconnecting between university and school as the basis of pre-service teachers' professional development. Pre-service teachers' pedagogical skill will differ according to the context where they have conducted teaching rehearsal. Kazemi (2015) and also Horn (2010) found that Mathematic pre-service teachers' understanding of their students, subject and teaching activity influenced their rehearsal teaching performance. In addition, their classmates shaped their teaching attitude in choosing their preferable teaching approach.

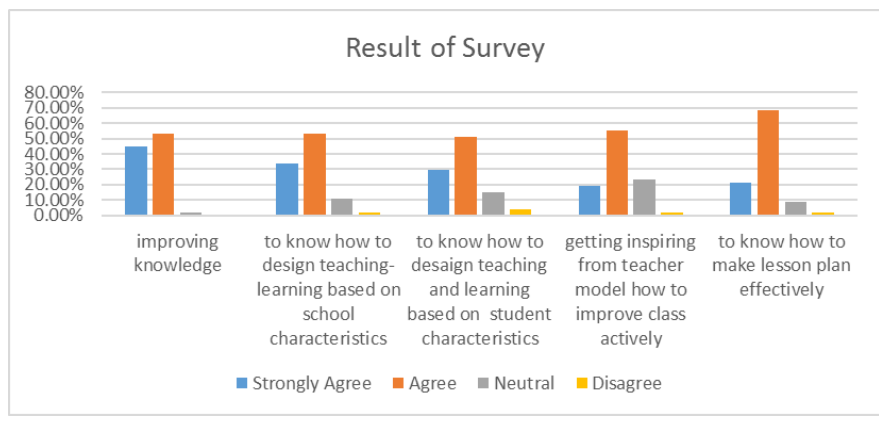

Fig. 3. The result of the survey on implementing Rehearsal Model based on Knowledge aspect

As it is shown in the graphic above, Rehearsal Model gives pre-service teachers chances in developing their general knowledge in teaching and learning process. Although not all pre-service teachers chose 'strongly agree', but graphic shows that the 'strongly agree' and 'agree' answer choices were dominant. Rehearsal Model gives more chances to pre-service teachers compare to the chances given through previous practicum module system. Rehearsal Model system is able to refresh knowledge that pre-service teachers has stored in their memory throughout the Microteaching classes.

Moreover, they also gained the skill of incorporating learning needs with school and students' characteristics. In this step they finally realized that designing a good learning activity was not only based on the school's regulation because each context is different. The graphic also shows that in average, pre-service teachers were given a chance in designing teaching activity that was suitable for particular school and students context

Rehearsal model also introduces effective class management. The model teachers who had been observed in the beginning of the program, inspired pre-service teachers on how to manage the class well. They were also inspired on how to conditioned the class so that students were ready to learn, and how teachers had various ways in managing the 
class. These lessons will not be gained if pre-service teachers only depended on peerteaching/ microteaching classes. Through the combination of in-class microteaching and real class teaching, pre-service teachers have learned effective class management techniques.

Rehearsal is practice process for pre-service teachers to improve their teaching skill. Other than rehearsal, Instructional Activity (Lampert and Graziani, 2009) that was modeled by their lecturers is also an effective method for pre-service teachers in choosing their teaching method. Lecturers' Instructional Activity will inspire pre-service teachers when they rehearse. Lecturers are pre-service teachers' role model. Lecturers creativity in conducting instructional activities affect pre-service teachers in teaching. Pre-service teachers who were taught by more creative lecturers will most probably teach better. They will not only ponder about 'how to teach' but also 'how to facilitate' students so that they will learn actively.

The chances given to pre-service teachers through the implementation of Rehearsal Model has improved their skills in creating teaching media. They have received the theories in the class, but teaching rehearsal has refreshed their knowledge. They have also learned from teachers whom they have observed. Pre-service teachers have also had the chance to implement their knowledge on learning design which they have learned in the second and third semester.

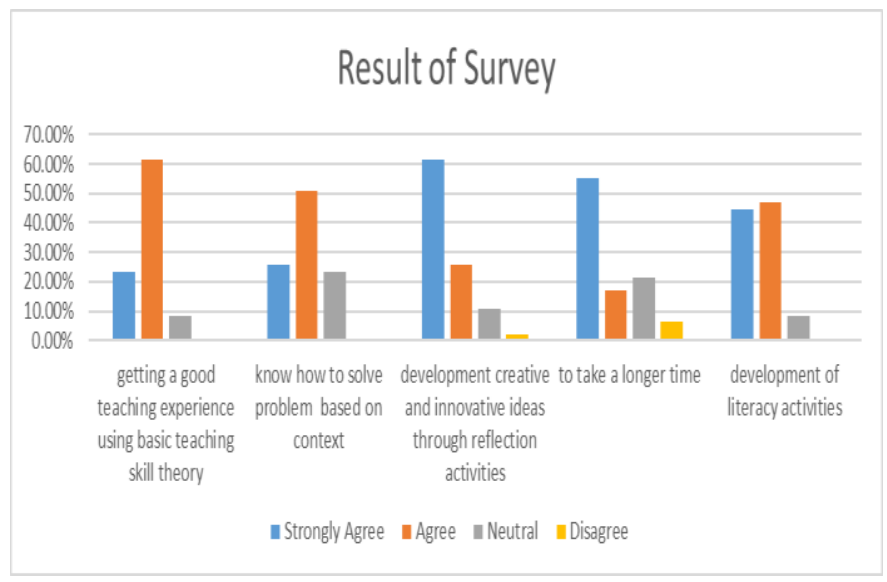

Fig. 4. The result of the survey on implementing Rehearsal Model based on Skill Improvement aspect

The survey result on skill improvement aspect can be seen in the above table. Data shows that pre-service teachers could learn basic teaching skill well. Basic teaching skill are skills use to open and close the lesson, to give questions, to summarize or drill, to make variation, to explain and elaborate, to guide discussion, to manage class, and to teach a few number of students or individual student. In average, pre-service teachers obtain the knowledge through observation process. Most pre-service teachers answered 'agree' and 'strongly agree.' It shows that their understanding and knowledge received from Microteaching classes were strengthen through observation and real teaching process.

Rehearsal Model also give chances for pre-service teachers to solve problems dealing with specific student characteristics. Problems that have been solved were related to differences in learning characteristics. Theories explained various learning problems; however, when pre-service teachers exposed to real problems, they were learning by doing. Pre-service teachers also learned that each child is different and unique. Therefore, each problem needs to be handled differently. Through this process, pre-service teachers learned the art of teaching.

In practice, rehearsal model allows transfer process to happen. The ones that could be transferred are values and knowledge. Transfer theory states that an activity will have bigger impact in changing one's vision. Previous experience will be replaced by new experience. Transfer theory and rehearsal in this context are integrated (Bransford and Schwartz, 1999). In their study, Bransford and Schwartz found that pre-service teacher teaching practice will help create teacher values when they finally become teachers.

Teaching practice using Rehearsing Model also serve as an innovation in helping pre-service teacher to be more creative. This is because at the end of the semester, preservice teacher needs to display their teaching result in an exhibition. The exhibition will also be attended by the teachers they have observed and learned from. This way, pre-service teachers will be more motivated to in applying innovative and creative techniques, handout, realia and media.

When asked about whether the credit of Microteaching module (PPL1) needs to be added, the dominant answers were 'strongly agree.' Laboratory department take the answers as a suggestion and will review the curriculum for Microteaching module (PPL1) together with the faculty. Rehearsal Model also gives a good literacy experience. Literacy activity should be integrated with teaching activity. Literacy activities such as: reading, discussion, listening, writing the summary of the discussion, video making, map making, diagram making, drama performance, poetry performance, song lyric adaptation, and mind mapping, exist in Microteaching module (PPL1). These activities will inspire pre-service teachers in creating enjoyable and high qualified teaching learning activity in real context. They would also learn that innovative teaching and learning will help literacy culture to be developed.

Data shows that preparation is not an easy task for preservice teachers. It is complex and full of challenges. It does not involve one person only, but it requires synergy between components. Producing professional teachers is the main responsibility of teacher training universities. The production process involves knowledge, skill, and disposition (FeimanNemser, 2001: 1013-1055). Teachers do not only facilitate students to acquire knowledge, but also develop students' skill and attitude.

In Indonesian context, those are known as: attitude, knowledge and skill. Several aspects in pre-service teacher 
preparation program that need to be focused on are: analyzing teachers' belief and shaping new learning vision, developing teaching subject, developing students' understanding, developing new teaching tools (Feiman and Nemser, 2001: 1013-1055).

\section{CONCLUSION AND SUGGESTIONS}

a) Rehearsal Model as a new model in Microteaching module (PPL1) prepares English pre-service teachers toward Internship program (PPL2). Pre-service teachers are hoped to be more professional when they do the internship. There are 6 steps in Rehearsal Model: observation, collective analysis, preparation, rehearsal, classroom enactment, and collective analysis. These steps are developed into: introduction, real class observation, observation data analysis, preparation, microteahing and reflection, realteaching, reflection, whole course reflection, and finally exhibition plan.

b) Data shows that Rehearsal Model improves pre-service teachers significantly and that it will be a new practicum model that will be developed further by the Faculty of Tarbiyah and Teacher Training at UIN Sunan Ampel Surabaya.

\section{REFERENCES}

[1] Bransford, John D., and Daniel L. Schwartz. "Rethinking Transfer: A Simple Proposal with Multiple Implications." Review of Research in Education 24 (1999): 61. Web.

[2] C.Galambos, Eva. "Improving Teacher Education." San Fransisco London:Jossy-Bass Inc Publisher (1986).

[3] Feiman-Nemser, Sharon. "From Preparation to Practice: Designing a Continuum to Strengthen and Sustain Teaching." Teachers College Record Teachers College Rec 103.6 (2001): 1013-055. Web.

[4] Hodkinson, Gareth Harvard and Phil. "Action and Reflection in Teacher Education." Newjersey:Ablex Publishing Corparation Narwood (1994).

[5] Horn Iliana Seidel. "Teaching Replays, Teaching Rehearsals, and Re-visions of practice: Learning from Colleagues in a Mathematics Teacher Community." TeachersCollegge Record Volume 112, Number 1 Januari 2010, pp, 2225-259

[6] Kazemi, E., H. Ghousseini, A. Cunard, and A. C. Turrou. "Getting Inside Rehearsals: Insights From Teacher Educators to Support Work on Complex Practice." Journal of Teacher Education 67.1 (2015): 18-31. Web.

[7] Lampert, Magdalene, and Filippo Graziani. "Instructional Activities as a Tool for Teachers' and Teacher Educators' Learning." The Elementary School Journal 109.5 (2009): 491-509. Web.

[8] Rusydiyah, Evi Fatimatur, Kurniawan Agus, Setyowati, Maunah, Rahmawati, and Farisia, Hernik. Field Experience Guidance Book. UIN Sunan Ampel Press. (2015) 